\title{
Study on the Aesthetic Value of Public Art in the Process of Urbanization Junmei Wang ${ }^{1, a}$ \\ ${ }^{1}$ Public Art Education Centre, Xijing University, Xi'an, Shaanxi,710123 \\ ${ }^{a}$ email
}

Keywords: Public Art; Urbanization; Process; Aesthetic Value

\begin{abstract}
With the social and economic development, urban construction is the trend of development. Public art plays a critical role in the process of urbanization construction, it is possible to live, the construction process of urbanization, people's culture play a key role to some extent. Public art in the construction process of urbanization, which makes clear the target personalized construction. It is one of the important factors to improve the social and cultural level. In this paper, the process of urbanization in the constituent elements of public art, reflecting the aesthetic value of start to start talking about public art aesthetic value..
\end{abstract}

\section{Introduction}

Urbanization is one of the major carriers are now people's lives, with the advance of the urbanization process in China, the city's living environment is increasingly supported by the crowd. Public art refers to the art and corresponding environmental design freedom in public participation and recognition of public open space. In the form of public art performance varied by using a large number of sculptures, murals or decorative works in public view, transformation; build up a good social atmosphere.

\section{The Constituent Elements of Public Art}

The advance of urbanization is an important factor to develop public art, but also a test of the public aesthetic. Person as a subject of aesthetic, high quality of life with the requirements of people who enjoy public art at the same time is also creators of public art. Public art is reflected in the mood of people's lives, public art is a key element of people not avoid important social change factors.

Urbanization in the first public art should be people-oriented concept. To take into account the comprehensive integration of people with a sense of public art, to show the concept of change important factors of social development to a certain extent. For example, the construction of facilities in the Plaza of time to fully take into account the use of the people, public art is set to meet the level of appreciation of the public, to the overall development, the concept of public art into the design to. Improve the aesthetic concept of changing factors, the aesthetic element into the process of the construction of public art in the past.

Local culture is an important part of public art. Local culture allows the audience to accept public art can be able to promote the integration of public art in themes extent to some extent. Local culture is deeply rooted in local culture, it is one of the factors of urbanization construction process most can not lose. Xi'an Dayan outanane stands on the square "Xuanzang sculpture", representing the Buddhist culture of Xi'an, this building into the local religious culture conducive to Xi'an Xi'an people to accept, feel the beauty of art.

Now the construction of urbanization to meet the trend of social development, to meet the aesthetic ideas of the public. Therefore, in the urbanization process of building public art must meet the aesthetic values of the public. Aesthetic value of public awareness is reflected in the public recognition of public art, the public can mold character in these public art, to give an aesthetic enjoyment. For example, Monument to the People (Figure 1) is a good city public art in front of Tiananmen Gate China. People's Heroes Monument (monument to the people's heroes) is located in the center of Beijing's Tiananmen Square, about 463 meters south of Tiananmen Square, Zhengyang NATO 440 meters north-south axis is at the Government of People's Republic of China to 
commemorate the martyrs of the Chinese modern history and the construction of the monument. Monument to the People-high 37.94 meters, front (north) Monument heart is a single piece of stone, 14.7 meters long, 2.9 meters wide and 1 meter thick and weighs 60 tons, engraved with Comrade Mao Zedong wrote the "People's Heroes are immortal" eight gilt gold characters. 7 by the back of the monument heart stone structure, content drafting Mao Zedong, Zhou Enlai inscription written in 150 words. Monument to the People's certain extent represent the people fear of the hero, the dead soldiers miss. Public art in close contact with public life, from small street performance art, to the construction of public buildings, there is always a reflection of the public's living conditions. Public art can be abstract emotions into a public form of a solid artistic presence perceived.

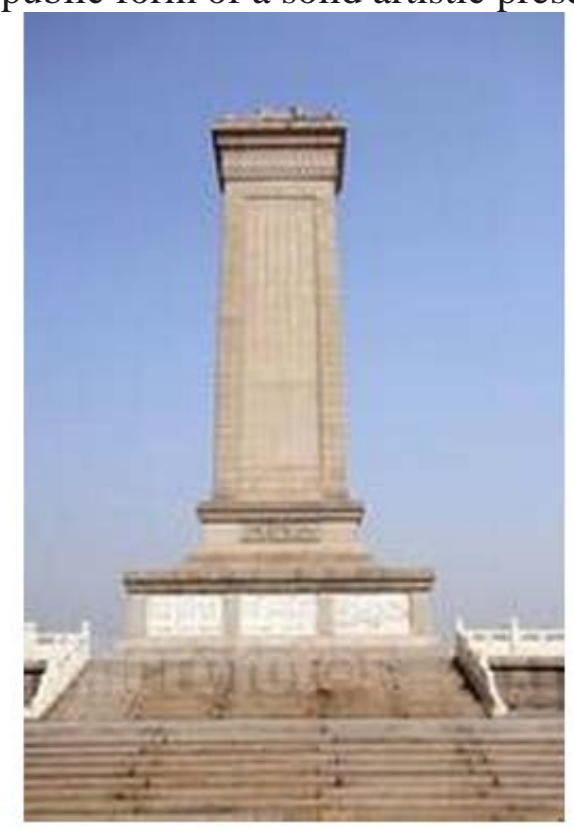

Figure. 1 People's Heroes Monument

Urbanization of public art to some extent above reflects the trend towards an era. Mass public art is a receptor, to accept things closely followed the trend of social trends. Every public art works reflect the social art of that period to a certain extent. For example, the University of Mexico Library Main facade of the mural design, which mainly uses 25 kinds of cultures different natural color image lava balanced symmetrically organized from different periods in Mexico, the first picture that enhances the sense of the library wall, second it can create a certain culture library, making the whole ambience of the library to a certain height. Into the fashion element can be to a certain extent, easy to keep up with the trend of the times, which will help the public to accept.

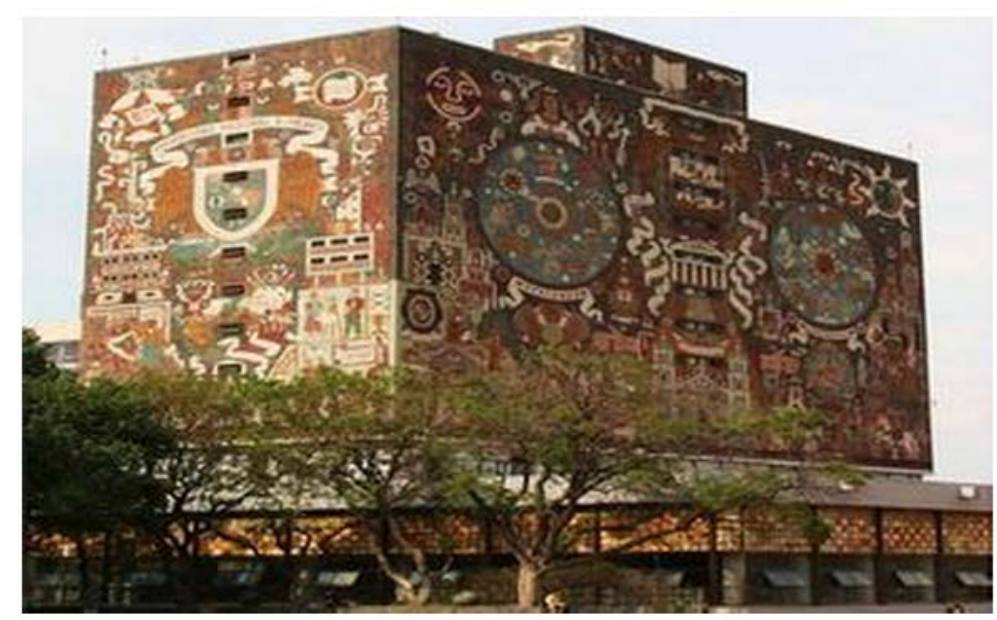

Figure.2 Mexico University Library Main Building exterior wall frescoes (Figure II) 


\section{The Process of Urbanization Reflects the Aesthetic Value of Public Art}

With the social and economic development, quality of life continue to improve, the level of urbanization construction continue to increase, public art as urbanization construction of important factors, it requires a combination of forms of social transformation in order to continue to exist for society.

To create a good social atmosphere, to improve the social environment of beauty, it is one of the key factors of public art. Public art can decorate the city's environment, a space art. A large number of urban construction to a certain extent, it is possible to create a harmonious living environment. For example, the majority of our city streets distribution boxes are white or blue-based, relatively single, but a precedent Wuhan, the distribution box is designed to combine the factors of age, the distribution box Exterior landscaping. The first can be able to present the richness of people's culture, second to show the degree of prosperity of the people of Wuhan, some create a social atmosphere of harmony.

Specific environment in order to produce public art, public art works will be able to reflect local aspects of life, by the local folk customs of. Above a certain degree can highlight distinctive local style. Must be able to represent a positive outlook on life, values for the formation of the local population has a positive guiding role.

Art popular participation is public art, it represents the people loved the art form, representing the aesthetic ideas of the public. Occupation in order to be accepted by the public, it forms a certain extent, in a subtle impact on people's behavior. For the promotion of a harmonious society has a role can not be separated.

The process of urbanization has brought urban culture is so common, a large number of urbanization, building on people's sense of visual fatigue, this time need to come into the public art element of transfers. City Public Art is art in a class, but it is the most close to people's lives, people's lives can reflect ideology. Zhengzhou 27 Monument for example, this is an important landmark building in Zhengzhou City, although the completion of sixty years of history, after several repairs, but its existence is still a great value, it must be able to extent, on behalf of Zhengzhou industrious people, for future generations is an incentive effect. Zhengzhou 27 Monument construction is reflected in the public's aesthetic ideas.

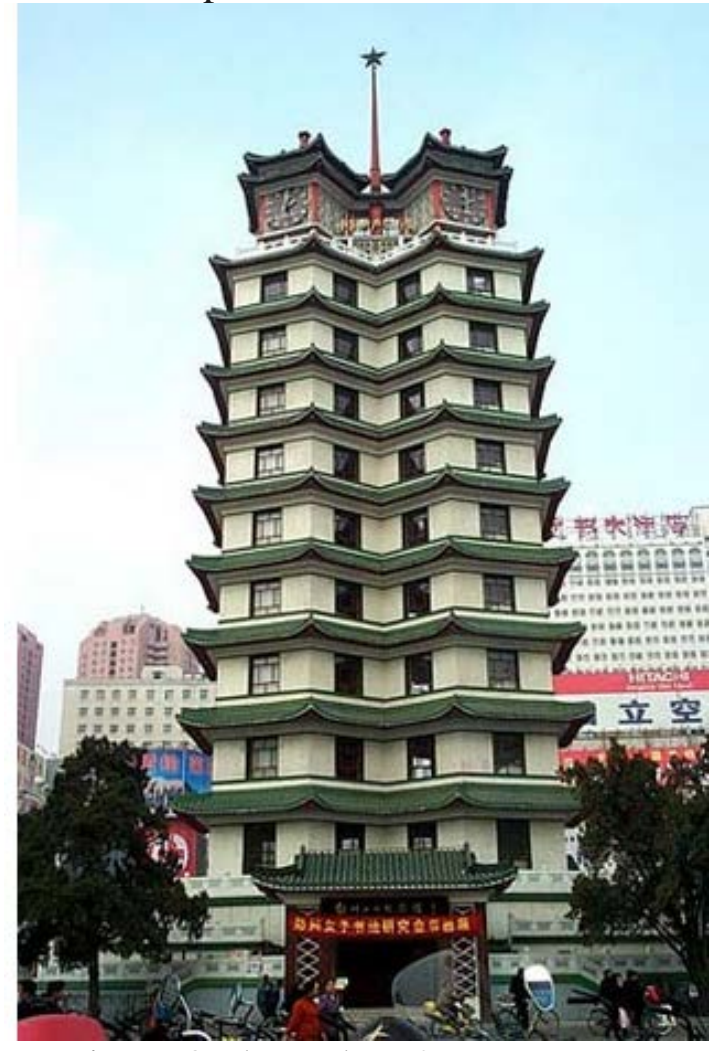

Figure.3 Zhengzhou 27 Monument 
Urbanization is an inevitable trend of social development, is a product of the modern economy, urban construction is the result of joint efforts of the public. Urbanization is a public audience, is the recipient. Public art carries into public attention on urban construction, people can be in the process of urbanization, the construction of public art, reflecting on changes in the values of their own life inside. Such as Dalian Xinghai Square sculpture "Road", this sculpture is an important work of art Dalian public participation, "Road" is a 1000 live-action constituted footprints, each pair of footprints is a step into the public, representing the public participation, these footprints from north to south to the sea, the implication is hard-working people to forge ahead in Dalian, Dalian create prosperity. Reflects the participation of the people of Dalian, Dalian is the era of the memory of the people. The greatest feature of the urbanization construction is the essence of the culture created by the people themselves, so that people can be able to enhance the degree of identity.

Urbanization is now a trend of social development, is now reflected in important mode of life. Since the reform and opening up, China's accelerating urbanization construction requires a wide range of communication and integration, in order to meet people's increasing level of spiritual and cultural consumption. Public art as a relatively high degree of public participation in art forms, more and more public concern.

Represents an important condition for social development factors; 1970s, urbanization construction in China has entered a significant phase of unprecedented development, China's urbanization to a certain extent represent the situation of China's economic development within the community one of the factors of change. For example, China Beijing Capital Airport construction, airport building into the 1970s a large-scale mural group, called for the birth of a number of classic public art, in content and form is reflected in ancient Chinese feelings, which incorporates Zhang Ding's "Conquers", Yuan Yunsheng "Splash", Yuan Yunfu's "Szechwan" and so on public art as an art form of public participation is also more and more people's attention. For example, in the suburbs of Tokyo, Japan has a "Tachikawa" station, built as a huge landscape sculpture park "Beautiful Fairy of the Forest." So that the original barren place famous, not only in Japan, the country gained in importance, and are very famous in the world above. From the original to the sparsely populated sea of people, it led to a rapid growth in the local economy, an important manifestation of local economic development is the local rates of price growth. Tachikawa since the establishment of landscape sculpture park completely known, led to the development of local food and beverage industry, transportation, entertainment and other industries, increasing the local income.

Sustainable development is an important current trend of social development, public art must be combined and ecology. As a national policy in line with national sustainable development, and secondly to establish a beautiful environment society. Urbanization is now advocating green ideas integration, the first is to protect the local ecology; the second is to help alleviate the urbanization bring people spiritual tension. Urbanization brought about a trend that becomes fast-paced economic development, a large number of buildings into people's lives, study, work, people's visual fatigue, green elements into the need to ease the people's vision fatigue. Public art to a certain extent, reflect the needs of the people.

\section{The Process of Urbanization Protective Measures for the Aesthetic Value of Public Art}

Public art is now Urbanization important factor is also one important part of people's culture. Urbanization without government guidance, government is the chief engineer of urbanization, urbanization important construction projects without the support of the government. On the one hand is the financial support, the other hand is guiding technology. The Government has the resources most concentrated society. So the government should as a guide in the center of the development of public art around the idea of changing the public's aesthetic, can be above a certain level to promote a harmonious culture. Masses of people should also be actively involved in this activity, the protection of public art works. Each work of art is inseparable from public acceptance of the aesthetic ideas of the public, the public acceptance of the need to create public art works out better. Public works of public art should express support for continued public support is the driving 
force of these public art designers.

\section{References}

[1] Xia Yanjing. urbanization Artistic influence - City "public art" and the social role of urban art of life issues to explore [J] Hundred Schools In Art, 2010 (6): 25-32...

[2] YuWenlong. explore contemporary public art debut in China [J] Arts Education, 2008 (12): 140-141.

[3] Zhang Yao. Public Art Research in Urbanization [J]. Urban Construction Theory: Electronic Edition, 2013 (9).

[4] Xiong Shitao. New Urbanization of public art intervention urban space [D]. Central Academy of Fine Arts, 2014.

[5] Du Chunlan, Wang Aijing. value of urban public art recognition [J] Shanxi Architecture, 2009, 35 (6): 38-39.

[6] Yeli Bing. Aesthetic value of the new city center design research [D]. Wuhan University of Technology, 2010.

[7] Liu Yuhua. From an aesthetic point of view of urban public art and design heritage and innovation [D]. Wuhan University of Technology, 2007.

[8] Zhang Li. Modern public art design aesthetic perspective [J]. Hua Zhang, 2011 (31). 